Relations industrielles

Industrial Relations

\title{
Walton, Richard E., Joel E. Cutcher-Gershenfeld, and Robert B. McKersie, Strategic Negotiations: A Theory of Change in Labor-Management Relations
}

\section{Richard B. Peterson}

Volume 50, numéro 3, 1995

URI : https://id.erudit.org/iderudit/051041ar

DOI : https://doi.org/10.7202/051041ar

Aller au sommaire du numéro

Éditeur(s)

Département des relations industrielles de l'Université Laval

ISSN

0034-379X (imprimé)

1703-8138 (numérique)

Découvrir la revue

Citer ce compte rendu

Peterson, R. B. (1995). Compte rendu de [Walton, Richard E., Joel E.

Cutcher-Gershenfeld, and Robert B. McKersie, Strategic Negotiations: A Theory of Change in Labor-Management Relations]. Relations industrielles / Industrial Relations, 50(3), 661-663. https://doi.org/10.7202/051041ar

Tous droits réservés (C Département des relations industrielles de l'Université Laval, 1995
Ce document est protégé par la loi sur le droit d'auteur. L'utilisation des services d’Érudit (y compris la reproduction) est assujettie à sa politique d'utilisation que vous pouvez consulter en ligne.

https://apropos.erudit.org/fr/usagers/politique-dutilisation/ 


\section{Strategic Negotiations: $A$ Theory of Change in Labor-Management Relations}

by Richard E. WALTON, Joel E. CUTCHER-GERSHENFELD and Robert B. MCKERSIE, Boston, Harvard Business School Press, 1994, 376 p., ISBN 0-87584$551-7$.

This book lays out a theory of strategic negotiations that encompasses, but also goes beyond, the first and third authors' well regarded A Behavioral Theory of Labor Negotiations that was published by McGraw-Hill in 1965. The authors explain that this book goes beyond their 1965 volume because the situation in the 1980s and early 1990s differ from those in the 1960s. Present conditions differ both in terms of the higher and more complex stakes and the fact that the labor-management processes and structures are more varied, complex, and subtle than before.

Their behavioral theory is expanded in several ways. First, they have recognized changes both in the social contract and substantive bargaining outcomes. Second, they have introduced three specific strategies; namely, strategies of forcing change, fostering change, and escaping the relationship. Third, they have expanded their analysis to include negotiation structure. Fourth, they have formalized the analysis of various environmental factors that impact the bargaining relationship. Finally, the authors have sharpened the linkage between tactics and strategies. They believe their revised, and enlarged, theory allows for testing of theoretical propositions that goes beyond the analytical model detailed in the behavioral theory.

Like their 1965 book, they use case studies of real-union-management relationships. Unlike their earlier work, they concentrate on both the social contract and the bargaining relationship in 13 different recent union-employer situations covering three specific industries: pulp and paper, auto supply, and the railroad industry. Most previous case studies have focused almost entirely on the negotiation and renegotiation of the parties' labour contract. This book adds the use of social contracts that define the way that both sides will use the "rules of the game" and how one party seeks to redefine the ongoing relationship at times. The authors address the social contract at both the institutional (union and employer) and individual (employee and supervisor/manager) levels.

The book is divided into four major parts or sections. Part I consists of three chapters that review current labour-management relations and lay out their theory of strategic negotiations. Chapters 4, 5 , and 6 (Part II) provide 13 rich case studies of recent labour-management relationships in the pulp and paper, auto supply, and railroad industries respectively.

Part III consists of two chapters. Chapter 7 focuses on the industry-wide factors that help to explain or influence the negotiations' strategic choices. On the other hand, Chapter 8 shifts the focus to a more detailed treatment of possible explanations for the strategic choices taken by the negotiators at the company or plant level. Finally, Part IV consists of four chapters. Chapters 9 through 11 provide illustrations of how the specific key negotiators in the different case studies tactically implemented their strategy by means of forcing, fostering, or using the two change processes in combination or in sequence. Chapter 12 summarizes the authors' findings in light of their theory of strategic negotiations, and argues the advantages of their negotiations framework over other theoretical perspectives.

Their use of qualitative research in doing in-depth case studies with key union and employers in 13 different firm and plant sites was particularly appropriate for gaining insights into what was taking place in labour-management relationships in three industries in recent 
years. A positivist research methodology would have yielded less powerful insights into the changing of strategy and tactics of the moving party in these case situations. While each of these three industries are one of many, the story told seems generalizable to what has taken place in many U.S. industries in the past 10-15 years. This does not negate the fact that some American industries have been relatively free of the "shocks" of increasing domestic and international product competition, corporate restructurings, the decline of company loyalty, mergers and acquisitions, and the growing central emphasis on the firm's "bottom line".

The authors' theory or general framework for analyzing a strategic negotiation is not particularly difficult to understand. The model identifies three major boxes or variables. The first of them consist of the two forces shaping negotiations' choices: desirability of change and feasibility of change. The authors' correctly point out that the need for change does not necessarily mean that it is feasible too. Change is expected to impact the interaction system that incorporates negotiating strategies, processes, and structures. The moving party may use forcing, fostering, or a combination of the two negotiations strategies and tactics to gain necessary objectives.

Finally, the outcomes box in their theoretical framework shows that such strategic negotiations can have an impact on both the substantive terms of the labour contract and the social contract itself. Their theory of strategic negotiations is laid out in greater detail in Chapter 3 , as are a set of broad hypotheses derived from their model. The more specific hypotheses can be tested a priori by using an experimental design similar to those used by social psychologists.

What makes this book a "must read" for anyone interested in industrial relations? First, for those who have read
Walton and McKersie's A Behavioral Theory of Labor Negotiations, it provides a more dynamic model of labourmanagement relations and the collective bargaining process than was captured in the more stable period of the 1950s and early 1960s. Most readers focused on their description of distributive, integrative, and mixed model bargaining, and gave less attention to the attitudinal structuring process. Change is at the center of their present strategic negotiations model.

Second, a reading of the case studies provides few, if any, illustrations of the union as the moving party in forcing and/or fostering change in either the social contract or the terms of the collective bargaining agreement. Rather, their cases center on the strategic choices available to management in enabling or forcing change in the bargaining relationship. The union negotiators were given fewer choices on how they would or could respond to the new agenda. This strategic choice perspective of industrial relations was developed by Kochan, Katz, and McKersie and their students at MIT in the early to mid1980s. The stories here are quite different than most of the cooperative programs that emerged in the 1960s in the U.S. like the Human Relations Committee in Steel, the Armour Automation Fund, and the Kaiser Progress-Sharing Plan where the union played a more equal role in the effort.

Third, the joint effort benefits from Richard Walton's contributions to the book. His expertise in organizational development represents one of the central fields to our understanding of organizational change - a force that is crucial to understanding present-day labour-management relations.

Fourth, their case studies covering twenty periods of strategic negotiations designed to force union concessions and/or foster union-management cooperative efforts is a good "read" as the 
authors highlight the factors of change in the industry or company, and how they were played out in the particular situation. Finally, their theory, and the propositions derived from it, provide academic researchers a new gold mine for testing our understanding of changing labour-management relations. Perhaps at a future time we will be able to observe American unions playing a more active role in fostering or forcing change to better balance the relationship between management and its employees (union or nonunion) than one finds in the current scene in many industries. It was a pleasure to read the book, and an added pleasure to review it.

RICHARD B. PETERSON University of Washington

\section{Le syndicalisme : état des lieux et enjeux}

par Mona-Josée GAGNON, Québec, Institut québécois de recherche sur la culture, Coll. Diagnostic, 1994, 140 p., ISBN 2-89224-243-6.

À une époque où pour plusieurs la crise du syndicalisme met en cause son existence même, le volume de MonaJosée Gagnon a pour mandat de " poser les jalons dans la réflexion sur le passé et sur le présent, mais surtout sur l'avenir du syndicalisme" (p. 10). En plus d'enseigner la sociologie à l'Université de Montréal, l'auteure travaille depuis vingt ans au Service de la recherche de la Fédération des travailleurs et travailleuses dụ Québec. Son ouvrage constitue un matériel intéressant pour le grand public car il lui fournit les données essentielles pour se faire une idée précise et éclairée de la situation actuelle du syndicalisme et des défis qui se posent à lui s'il veut garantir son existence, comme acteur économique c'est sûr mais surtout, comme acteur politique.

La structure de l'ouvrage repose sur deux grandes parties. La première veut faire le point sur l'état actuel du syndicalisme pour y parvenir l'auteure discute, à l'intérieur de trois chapitres, de l'encadrement juridique des relations du travail, de la syndicalisation et enfin de la composition du paysage syndical. Après avoir établi au début du chapitre un que les modes d'accès à la syndicalisation sont prescrits par l'encadrement juridique, Gagnon ajoute que la loi est vitale au fonctionnement des syndicats car elle leur donne les assises pour obliger les employeurs à négocier. Vient ensuite une description concise de l'appareillage juridique. Enfin, l'auteure présente deux cas particuliers au Québec, le secteur public et celui de la construction. De son avis, les régimes d'encadrement juridique de ces secteurs ne satisfont à peu près personne, bien qu'ils soient sujets à de fréquentes modifications. Selon nous, l'intérêt de ce chapitre est qu'il met en relief le rôle politique du syndicalisme. Comme on le sait, les lois sont le résultat de pressions exercées par différents groupes et si le mouvement syndical souhaite voir adopter des lois en sa faveur, il y va de son intérêt de s'impliquer en tant qu'acteur "politique ". Et Gagnon montre de façon claire qu'au Québec l'action syndicale dans la sphère publique a été permise et facilitée par l'encadrement juridique.

L'auteure amorce le chapitre deux en prévenant le lecteur de se méfier des statistiques en raison du choix méthodologique caché derrière les analyses. Elle continue en présentant deux faits irréfutables, selon elle, de la situation québécoise: l'encadrement juridique des relations du travail encourage la syndicalisation tandis que l'évolution du marché du travail, caractérisée par une hausse des emplois précaires dans les entreprises de services, la freine. Ensuite, sans contester le succès de la syndicalisation, l'auteure y met un 